Uniwersytet Łódzki

\title{
Kobiety w migracjach przesiedleńczych w Peru (1980-2000)
}

Przemieszczenia ludności w Peru przed wybuchem konfliktu zbrojnego
w 1980 r. miały podstawy ekonomiczne i wynikały, jak w innych krajach południowoamerykańskich, z krajowych uwarunkowań strukturalnych. Zaliczyć do nich należy przede wszystkim „głód” ziemi (nierozwiązany przez reformę rolną z 1969 r.) oraz odwieczne głębokie dysproporcje w poziomie życia obywateli zamieszkujących tereny wiejskie i miejskie na obszarze sierry i costy stanowiących pozostałości kolonialne. Peru w końcu XX wieku nadal charakteryzował nierównomierny wyspowy rozwój gospodarczy przy jednoczesnym braku szerszej koncepcji zmian zmierzających do niwelowania tych różnic. Dla terenów sierry typowa była archaiczna gospodarka rolna nie różniąca się specjalnie od okresu późnokolonialnego, której reformy końca lat 60 . niewiele zmieniły. Towarzyszący temu brak rozwoju podstawowej infrastruktury - słaba sieć dróg, trudności z wodą pitną, brak elektryfikacji, nieobecność większości urzędów państwowych - wszystko to podtrzymywało istniejący podział kraju nie tylko w poziomie rozwoju ekonomicznego, ale także w zakresie społeczno-kulturowym i politycznym. Utopijne okazały się też, a agresywnie w tym czasie lansowane, plany rozwoju, industrializacji i modernizacji kraju. Wywołały one jedynie intensywne fale migracji ludności wiejskiej, których celem miała być poprawa warunków życia w miastach (Golte 1987, Degregori 1986). Dlatego też miejscem docelowym migracji lat 70. stały się najlepiej rozwinięte stolice departamentów: Lima, Arequipa, Ica, Piura. Ta pierwsza ekonomiczna fala migracji miała odegrać w kolejnym dziesięcioleciu swoją nieznaną powszechnie rolę (Franco 1992).

Zgoła odmienne podstawy miały przemieszczenia ludności rozpoczęte w dekadzie lat 80., a trwające aż do końca XX w. Przesłanką tych migracji była przemoc polityczna panująca na terenach górskich.

Wskutek wewnętrznego konfliktu zbrojnego w Peru rozpoczął się w tym okresie exodus ludności rekrutującej się spośród osób uciekających przed przemocą z terenów sierry. 
W 1980 r. Świetlisty Szlak, organizacja ultramaoistyczna wywodząca się ze środowisk klasy średniej, rozpoczął konflikt zbrojny w jednym $\mathrm{z}$ najuboższych środkowoandyjskich departamentów - Ayacucho, ścierając się z siłami państwowymi (policji, a potem wojska). Władze państwowe źle oceniając siły, wpływy guerrilli oraz nastroje panujące wśród lokalnych społeczności wiejskich (zamieszkałych przede wszystkim przez Indian) odpowiedziały przemocą na niczym nieuzasadnioną skalę wobec ludności cywilnej. Paradoks historii polegał na tym, że terror ze strony państwowych sił zbrojnych wprowadzony został w tym samym roku, gdy miały miejsce pierwsze po 15 latach dyktatury wojskowej wybory demokratyczne, a stolica była gospodarzem światowej konferencji przeciw przemocy politycznej (Stern 1999:22; Blondet 1999:71).

Wskutek błędnych decyzji politycznych osób sprawujących władzę, a prognozujących rozwój wypadków z perspektywy stolicy i kierujących się w swych działaniach starymi uprzedzeniami etnicznymi (paternalistyczną nieufnością wobec Indian), cała ludność z terenów górskich, gdzie toczył się konflikt, uznana została za rebeliantów. W rzeczywistości w tym czasie tylko niewielki procent mieszkańców terenów górskich miał powiązania z guerrillia. W ten sposób wszyscy mieszkańcy tamtego regionu niezależnie od wyznawanych poglądów znaleźli się pomiędzy dwoma frontami ofensywy zbrojnej. Ofensywa państwowych sił zbrojnych skierowana była generalnie przeciw młodym ludziom z nowej klasy średniej, wśród których SL rzeczywiście miał wielu zwolenników i przeciw wszystkim mieszkańcom terenów wiejskich, których utożsamiono odgórnie i bezpodstawnie z terroryzmem.

Wobec dwóch ścierających się sił i niezrozumiałych dla mieszkańców terenów wiejskich przyczyn przemocy, ludność tubylcza przyjęła dwie opcje. Pierwszą były ucieczki i migracje przesiedleńcze, a drugą organizacja oddziałów samoobrony lub przystępowanie do guerrilli. Pierwsza opcja była inicjatywą oddolną, samoistną, niezorganizowaną i niekontrolowaną. Druga odgórna, sterowana i kontrolowana przez władze wojskowe lub przywódców guerrilli, zrodziła nowe formy przemocy, co stało się kolejną przesłanką potęgującą proces migracji. Część ludności w ramach drugiej opcji skłaniała się wskutek głębokiego poczucia niesprawiedliwości ze strony policji, jak i indoktrynacji lewicowych emisariuszy ku guerrilli. To rozpętanie przemocy ze strony władz sprawiło, że baza społeczna zwolenników guerrilli zaczęła gwałtownie rosnąć, a nastroje społeczne zdecydowanie zwróciły się ku nowemu ruchowi. Na decyzje te wpływ zasadniczy wywarła przemoc państwowych sił represji utożsamiających ad hoc wszystkich mieszkańców sierry z terroryzmem. 
Przesiedlenia w Peru w okresie 1980-2000, zwanym dziś okresem przemocy, są problemem niezwykle ważnym, choć długo bagatelizowanym, marginalizowanym, wypaczanym, a nawet wykorzystywanym w rozgrywkach politycznych (Revollar 2000:133).

Losy migrantów jako znaczącej grupy społecznej umykały na ogół autorom opracowań traktujących o okresie konfliktu. Dopiero dziś po ukazaniu się raportu CVR rozliczającego okres (1980-2000) zaczyna się mówić o przesiedleniach jako jednej z najpoważniejszych konsekwencji urazowych wojny domowej, zaraz po zabójstwach i zaginięciach (Dios 2003:57).

Celem mojego artykułu jest ukazanie trzech kluczowych, a zarazem mało znanych aspektów migracji: różnych (a nie jednorodnych) przyczyn i konsekwencji przesiedleń, roli płci w migracjach oraz dyskryminacji kulturowej, z jaką przyszło borykać się migrantom.

Artykuł oparty jest w znacznym stopniu na materiałach zebranych w trakcie badań terenowych autorki prowadzonych w latach 2004-2005 w Peru (w ramach grantu KBN 2HO1H 002265).

Migracje przesiedleńcze 1980-2000 były procesem długotrwałym, zróżnicowanym, o zmiennej skali natężenia obejmującym wg szacunkowych danych od 600 tysięcy do 1 miliona obywateli, a wg innych źródeł nawet 3 miliony osób. Migracje dotyczyły od 120-200 tysięcy rodzin wg jednych a 500 tysięcy wg innych źródeł (Coral 1994:8; Dios 2003:60). Trudności w ustaleniu liczby tej fali migracji wynikają z faktu, że do $1981 \mathrm{r}$. w Peru nie istniały krajowe spisy narodowe, a do 1992 r. żadne rejestry dotyczące przesiedleń. Nawet i po 1992 r. problemy migrantów nie były badane całościowo, a tylko w wybranych prowincjach (Blondet 1999:27). Stąd też dane są tak zróżnicowane i przypuszczalnie znacznie zaniżone. Wiemy jednak, że wybrane stolice prowincji podwajały i potrajały liczbę swych mieszkańców wskutek napływu ludności wiejskiej już w pierwszych pięciu latach wojny. Fala przesiedleńcza tego okresu odbiła głębokie, poważne piętno na dzisiejszej rzeczywistości Peru. Około 380 osad i wspólnot znikło w tym czasie z mapy Peru, większość wskutek zniszczeń wojennych, ale część także wskutek opuszczeń (CVR 2003:1222).

Przyczyny migracji były spolaryzowane, dzieląc przesiedleńców na 3 zasadnicze grupy: tych, którzy uciekali przed przemocą i okrucieństwami wojska oraz tajnej policji - ta przyczyna dominowała w pierwszych migracjach pomiędzy 1980 a 1983 rokiem; tych, którzy uciekali przed przemocą guerrilli po 1983 roku i tych, którzy uciekali generalnie przed okrucieństwami wojny na równi sił zbrojnych, tajnej policji, guerrilli, od- 
działów samoobrony oraz sił antynarkotykowych działających pod auspicjami władz.

Prawdziwa motywacja migrantów z pierwszej i trzeciej grupy była wyciszana lub wypaczana wobec opinii społecznej do 2002 roku (Diez 2003:110).

Mieszkańcy sierry wskutek przemocy politycznej migrowali w kilku kierunkach - do miast na wybrzeżu (przede wszystkim do Limy), do pobliskich względem miejsc pochodzenia miast i miasteczek Andyjskich (Ayacuchoselvy centralnej, Huancayo, Junin) oraz w pobliże baz wojskowych, a także w kierunku selvy centralnej.

Reakcje środowiska przyjmującego w każdym wypadku były nieco odmienne, a więc też i różnie układały się losy migrantów w zależności od obranego kierunku przesiedlenia.

W migracjach przesiedleńczych okresu 1980-2000 wyróżniamy 3 okresy:

I. 1980-1983 tzw. okres inicjalny,

II. 1983-1990 - tzw. właściwy, gdy migracje osiagnęły najbardziej masowy charakter,

III. 1990-2000 - migracje powtórne łączone po 1995 r. z próbami reemigracji (INEI 1998).

Pierwszy okres tzw. inicjalny (1980-83) objął tylko mieszkańców dep. Ayacucho. Początkowo miał na celu profilaktyczne odsuwanie najbliższych wybranych członków rodzin od rozwijającego się teatru wojny na terenach wiejskich poprzez odsyłanie ich do pracy w rejony odległe interregionalne, najczęściej do krewnych przebywających już jakiś czas w mieście.

Przesłanką bezpośrednią był lęk przed arbitralnymi działaniami policji i wojska, a także groźba wpływów guerrilli na młodzież, która prowadziła aktywną politykę indoktrynacyjną, co niepokoiło wiele rodzin chłopskich. Miejsca migracji wynikały z tego, gdzie poszczególne rodziny miały swych krewnych. Rodziny kierowały wybrane osoby do bliskich znajomych, powinowatych do Limy, Huancayo i Ayacucho celem ich wyłączenia, izolacji, odsunięcia od niebezpieczeństw, jakie pojawiły się na terenach rodzinnych. W tej fali migrantów na ogół dominowali młodzi mężczyźni, choć w końcowym okresie w obawie przed przemocą seksualną ze strony Sił Zbrojnych nagminnie zaczęto wysyłać do miast także dorastające dziewczęta. Te grupy migrantów charakteryzował przede wszystkim młody wiek pomiędzy 13 a 18 lat.

We wsiach jako strażnicy własności wspólnotowej i dobytku indywidualnego zostawali ludzie starsi oraz kobiety z małymi dziećmi zakła- 
dający niesłusznie, że ich prześladowania nie dotkną w takim stopniu jak ludzi młodych. Mężczyźni walczyli w guerrilli lub byli wcielani do oddziałów samoobrony podporządkowanych władzom.

Druga fala migracji miała miejsce w latach 1983-1990. Objęła już nie pojedyncze osoby, lecz grupy kilkuosobowe, całe rodziny, lub raczej tych, którzy pozostali przy życiu w przedziale wiekowym 10-35 lat. Do miast uciekały grupy rekrutujące się z tej samej rodziny lub powinowatych. Główną przesłanką był lęk, brak poczucia bezpieczeństwa przed zróżnicowanymi protagonistami: policją, wojskiem, oddziałami samoobrony i guerrilli. Jednych charakteryzował lęk przed zabójstwami, torturami, gwałtami, porwaniami, innych konkretne traumatyczne doświadczenia utrata najbliższych, wymuszone uczestnictwo i obserwacja okrucieństw Sił Zbrojnych lub guerrilli (obie strony stosowały taktykę gromadzenia i obecności lokalnych grup w momentach tzw. wymierzania sprawiedliwości, które w rzeczywistości przemieniały się w publiczne mordy) utrata dobytku (spalone domy, grabieże dokonywane przez obie strony). I ta fala migracji dotyczyła przede wszystkim ludzi młodych, ale w szerszym przedziale wiekowym. W tej fali dominowały kobiety, wiele z nich podejmowało trud ucieczki z dziećmi (nie tylko swoimi).

Trzecia fala migracji z lat 1990-2000 obejmowała zarówno jednostki, jak i całe rodziny. Cechą charakterystyczną dla tego okresu były migracje powtórne oraz reemigracje. Wiele rodzin szczególnie z terenów selvy po raz drugi, a nawet trzeci, zmieniało miejsce zamieszkania uciekając ponownie przed przemocą, co wynikało z pełzającego rozszerzającego się zasięgu konfliktu. Znając już przemoc i zagrożenia sprzed kilku lat, w momencie ponownego pojawienia się guerrilli, sił antynarkotykowych oraz sił zbrojnych w nowym miejscu pobytu po raz kolejny porzucali domostwa w poszukiwaniu spokoju. W drugiej połowie tego okresu przesiedleń miały też miejsce pierwsze próby reemigracji, powrotów po wielu latach na tereny rodzinne, co związane było z wygasaniem wojny w prowincjach środkowoandyjskich i przesuwaniem terenu działań na wschodnie obszary selvy. Wszystkie próby reemigracji, mimo agitacji i wsparcia ze strony władz, kończyły się jednak niepowodzeniami.

Władze organizowały szumne pokazowe akcje pomocy ze strony państwa, jak i społeczeństwa cywilnego (kościoła, organizacji ONG) w momencie przesiedlenia potem pozostawiały reemigrantów samych sobie. Ich wieloletnie pobyty w środowisku miejskim były nie do zaakceptowania dla młodzieży nieznającej życia wiejskiego. Nawet przy okresach wsparcia ze strony władz na nowe zagospodarowanie, reemigranci 
chyłkiem po krótszym lub dłuższym okresie powracali do miast. Wynikało to poza przesłankami kulturowymi (obcymi dla dzieci reemigrantów) także $\mathrm{z}$ faktu stopnia zdewastowania regionów górskich w zakresie ekonomii, rozpadu organizacji społecznych. Istotnym czynnikiem było też dla reemigrantów ograniczone poczucie bezpieczeństwa. Lokalne prorządowe Organizacje Samoobrony o charakterze paramilitarnym nie budziły zaufania reemigrantów. To $\mathrm{z}$ ich powodu wielu przed laty wyemigrowało do miast. Ludność miejscowa także niechętnie przyjmowała reemigrantów, oceniając ich jako zdrajców, którzy opuścili ziemie rodzinne na rzecz „wygodnego" życia w miastach.

Wysoka skala przesiedleń z terenów górskich po 1980 r. dowodzi skali zagrożenia i braku poczucia bezpieczeństwa, jakie pojawiły się na terenach wiejskich wśród ludności cywilnej, stopnia rozbicia systemów ekonomicznych, mechanizmów pracy do jakich musiało dochodzić z powodu wyludniania określonych osad i regionów, braku podstaw zapewniających przetrwanie i funkcjonowanie rodzin.

Uciekającą z terenów górskich ludność charakteryzował określony zespół cech. Migrujący byli jednorodni, jeżeli chodzi o miejsce pochodzenia, przynależność etniczną i kulturową. W 77\% rekrutowali się spośród ludności Indiańskiej, a tylko w 23\% z metyskiej, wywodząc się z wiejskich departamentów w prowincjach Ayacucho, Huancavelica, Junin, a potem Puno (Cuanto 1997 i 2001). Ludność ta w przeważającej większości była monolingwistyczna posługująca się tylko językiem kiczua przy słabej znajomości hiszpańskiego charakteryzującej głównie mężczyzn. Migranci nie byli grupą shomogenizowana, jeżeli chodzi o motywacje przesiedleń, tzn. czynników jakie wpłynęły bezpośrednio na ich decyzję o porzuceniu miejsca pochodzenia. Zależne to było od charakteru migracji: dobrowolnej lub wymuszonej, wywołanej działaniami państwowych Sił Zbrojnych lub guerrilli. Przesiedleńców podzielić należy także z punktu widzenia miejsca migracji: na wewnątrz i interprowincjalne. Grupy przesiedleńców różniły się ponadto $\mathrm{w}$ zależności od odmiennych sytuacji, z jakimi borykały się po przybyciu do nowego miejsca pobytu co związane było z kolei z nastawieniem grup przyjmujących: pozytywnym, negatywnym lub obojętnym. Konsekwencją tego były różne drogi asymilacji lub adaptacji, oddolnej oraz odgórnej w nowym środowisku. Do dziś te właśnie elementy wciąż dzielą dawnych migrantów, chociaż przez lata fakty te skrywało.

Jedną z najistotniejszych cech migracji przesiedleńczych lat 1980-2000 w Peru było ich sfeminizowanie. Blisko $70 \%$ z migrujących stanowiły kobiety (CEPRODEP 1997; Cuanto 2001). Scharakteryzowanie roli płci jest 
elementem istotnym nie dlatego, że kobiety stanowiły zdecydowaną większość, ale także dlatego, że to one od początku były inicjatorkami przesiedleń, kierując się innymi celami niż mężczyźni oraz z powodu większych trudności, z jakimi przyjmowało je środowisko miejskie.

Gdy wojna, walka zbrojna była przede wszystkim problemem mężczyzn, (chociaż po stronie guerrilli walczyły także licznie kobiety) migracje przesiedleńcze stały się $\mathrm{w}$ dominującym zakresie problemem kobiet. Działania militarne (niezależnie czy po stronie pro- czy antyrządowej) miały charakter zorganizowany odwrotnie niż migracje. Gdy guerrillia i wojsko swoimi działaniami zmierzały do unicestwienia przeciwnika, migracje miały na celu zapewnienie bezpieczeństwa, obronę życia rodzin i dzieci. Ten cel nadrzędny wymieniały kobiety zarówno w momencie przesiedleń, jak i dziś po 20 latach. Dlatego też to opinie kobiet są tak ważne w badaniu procesu przesiedleń. Kobiety były niewątpliwie inspiratorkami pierwszej fali inicjalnej migracji, to one podejmowały trudne decyzje o wyborze i wysłaniu określonych członków rodziny z terenów górskich. Ich celem było odsunięcie bliskich od sceny przemocy. W drugiej fali migracji to kobiety jako pierwsze ścierały się z nowymi trudnościami i wyzwaniami, jakie niosło przesiedlenie, to one też brały na swoje barki formy przemocy, jakie pojawiały się w nowych miejscach osiedlenia oraz poszukiwały i wybierały różne drogi asymilacji i adaptacji dla najbliższych. $\mathrm{W}$ trzeciej fali migracji w próbach reemigracji to także kobiety były inicjatorkami powrotów na tereny rodzinne. Kierowały się tęsknotą za utraconym wyidealizowanym przez lata środowiskiem, których decyzji nie rozumiało zupełnie wychowane już w warunkach miejskich ich potomstwo.

W procesach migracji istotna była nie tylko płeć migrantów, ale też wiek i status rodzinny. Na migracje decydowały się kobiety młode pomiędzy 14 a 34 rokiem życia. 60\% spośród nich stanowiły kobiety samotne wdowy lub osoby, których członkowie rodzin uznani zostali za zaginionych. Kolejnym bardzo ważnym wyznacznikiem był fakt, że większość z nich była obarczona potomstwem, nie tylko własnym, ale także bliskich. Towarzyszące kobietom dzieci rekrutowały się także z nieletniego rodzeństwa lub osieroconego potomstwa krewnych.

Obie płcie w momencie migracji stykały się z dwoma trudnościami, takimi jak zmiany środowiska ekologicznego - z terenów wiejskich wysokogórskich, zimnych przenoszono się na obrzeża miast leżących często na wybrzeżu o zupełnie innym klimacie oraz całkowita utrata dobytku materialnego lub pozostawienie go na terenach porzuconych, co sprawiało, że przesiedleńcy przybywali do miast, mając świadomość swego ubóstwa. 
To kobiety charakteryzował jednak określony znacznie szerszy zespół cech niż mężczyzn.

Migrowały one po utracie partnera, rodziców lub dzieci w stanie ciężkiej traumy, gdy z dnia na dzień musiały stać się głowami rodziny. Najczęściej ze świadomością pozostawienia w miejscu rodziny starszych jej członków (rodziców lub dziadków) narażonych na przemoc. Większość $\mathrm{z}$ nich była $\mathrm{w}$ momencie przesiedlenia $\mathrm{w}$ fatalnym stanie fizycznym i psychicznym, z którym musiały sobie radzić (trudy migracji, rany postrzałowe, pobicia, gwałty). Ból po utracie najbliższych, strach, lęk, pamięć traumatycznych doświadczeń wyniesionych z miejsca pochodzenia i nowych, jakich dostarczało im obce nieznane środowisko miejskie. Większość była w stanie głębokich depresji, a część poważnie chora fizycznie. Stanowiły generalnie grupę szczególnie zdeterminowaną, co wynikało z faktu, że większość była obarczona nieletnim potomstwem (średnio od 3-5), o którego dalszy byt musiała walczyć w nowych warunkach.

Na kobiety spadała w momencie przesiedlenia konieczność dostosowywania się naraz do kilku nowych ról społecznych, głowy rodziny, żywiciela, który szukał nowych możliwości ekonomicznych zapewniających przetrwanie najbliższym, osoby oswajającej kulturowo najbliższych z nowym, nieznanym i im samym środowiskiem, osoby, od której umiejętności zależało nawiązanie nowych relacji społecznych niezbędnych do życia w nowych warunkach.

Podkreślić należy, że kobiety traciły w momencie migracji swoją dotychczasową tożsamość społeczną wynikającą z płci. Na terenach wiejskich były bardziej obciążone pracą niż ich rówieśnice w miastach (były żonami i matkami, a ponadto pracowały fizycznie na równi z mężczyzna$\mathrm{mi}$ ), ale w sensie społeczno-kulturowym ich status był zdecydowanie wyższy niż mieszkanek miast. Miały prawo głosu w strukturach zgromadzeń wspólnotowych, pełniły równoległe do męskich funkcje w życiu obrzędowo-rytualnym. Przenosząc się do miast na tereny o dominującej pozycji mężczyzny i obyczajowości macho znajdowały się w sytuacjach zupełnie nowych i nieznanych im z punktu widzenia traktowania kobiet.

Podstawowa trudność obok poszukiwań możliwości przetrwania ekonomicznego najbliższych stanowiły dla migrantek uwarunkowania kulturowe. Kobiety w znacznie większym stopniu niż mężczyzn charakteryzował brak znajomości języka hiszpańskiego, analfabetyzm, brak orientacji poruszania się w warunkach miejskich i jakichkolwiek kwalifikacji do podjęcia pracy. Mężczyźni mieli łatwiejszy start, gdyż mogli podejmować pracę wszędzie: w sektorze nieformalnym, ale często znajdowali też 
zatrudnienie jako niewykwalifikowani robotnicy na budowie czy w fabrykach. Kobietom pozostawał wyłącznie sektor nieformalny. Od ich inwencji zależał byt od kilku do kilkunastu osób. Ponadto mężczyźni często w warunkach miejskich mimo wspólnych traumatycznych przeżyć porzucali rodziny, dostosowując się do panującej obyczajowości machizmu, zakładając kolejne rodziny.

Ograniczeniem dodatkowym dla kobiet było odnalezienie się w społeczeństwie, gdzie wszystkie dokumenty wydawano na mężczyzn. W warunkach wiejskich w tradycyjnych strukturach nie stanowiło to przeszkody. W mieście odwrotnie - brak dokumentów był utrudnieniem, podobnie jak fakt samotności kobiet. Brak partnera utraconego na ogół w tragicznych okolicznościach nie stanowił powodu współczucia i mobilizacji otoczenia do pomocy jak było w miejscach pochodzenia, a narażał kobiety na dodatkowe stresy.

Samotność, brak partnera w mieście stawał się elementem dodatkowej traumy. Większość z kobiet nie była gotowa ani na nowe związki z mężczyznami, ani na akceptowanie niezrozumiałych wymogów, co utrudniało nie tylko relacje codzienne $\mathrm{z}$ otoczeniem, ale miało też swoje inne konsekwencje. Narażało kobiety na napaści na tle obyczajowym, rabunkowym i seksualnym.

Migrantki były dyskryminowane przez obowiązujące w kraju prawo i obyczajowość, z którymi nie miały nigdy wcześniej styczności. Niemal wszystkie nie posiadały żadnych dokumentów. Dopiero w latach 1990-1992 wprowadzono obowiązek wydawania dokumentów kobietom.

Mężczyźni przesiedleńcy, mimo że stanowiący mniejszość wśród migrantów mieli zdecydowanie łatwiejszy start w warunkach miejskich niż kobiety. Dostawali dokumenty, przydziały na jedzenie, instytucje pozarządowe wspomagały ich w poszukiwaniu pracy, gdy kobiety w biurokratycznych strukturach miejskich dekady lat 80. ginęły, co dodatkowo komplikowało ich życie. W nowych miejscach zamieszkania kobiety spotykały się też z wyższą skalą agresji, przemocy i dyskryminacji kulturowej niż mężczyźni, wynikającej z ich odmienności zewnętrznej, braku znajomości języka i faktu samotności (braku partnera).

Migrantki spotykały się z dyskryminacją kulturową, szczególnie zauważalną w wypadku przesiedleń interregionalnych. Miasta stosowały zróżnicowane formy nacisków i presji, które odbywały się przez lata pod okiem instytucji państwowych, jak i rozmaitych organizacji pozarządowych. Wobec przybyszy uruchamiano mechanizmy, które miały teoretycznie pomóc im, a w praktyce były wysoko urazowe. Wskutek tych 
nacisków doszło do nowej masowej fali metyzacji społeczeństwa peruwiańskiego i towarzyszącego temu znaczącego skurczenia grup identyfikujących się z pochodzeniem indiańskim. Te mechanizmy znów bardziej dotykały kobiet niż mężczyzn. Mężczyźni migranci i dzieci wizualnie nie wyróżniali się tak silnie ze środowiska miejskiego jak kobiety, nie poddawani presjom otoczenia w sposób naturalny zmieniali się. Kobiety jako odpowiedzialne za byt rodziny miały podstawowe kłopoty z porozumiewaniem się, mężczyźni z racji wcześniejszych na ogół kontaktów znali zawsze choć w minimalnym stopniu język. Kobiety wyróżniał wizualnie etniczny ubiór i uczesanie, co stawało się przedmiotem drwin, szykan i wyśmiewania otoczenia, czego po trudnych przebytych doświadczeniach nie były w stanie zrozumieć.

Ilustruje to wypowiedź jednej $\mathrm{z}$ migrantek $\mathrm{z}$ lat 80 .

„Wyśmiewano się z nas za strój, warkocze, dzieci noszone na plecach. Dochodziło do tego, że mój kuzyn udawał, że mnie nie zna aby w stołówce ludowej dostać jedzenie. My nie rozumiałyśmy z córkami dlaczego. Potem kuzyn dzielił się z nami tym co dostał, ale to było za mało na 4 osoby". (Salwy)

Drogi asymilacji i adaptacji były też różne, ale na ogół bolesne. Zdecydowanie łatwiejsze były dla grup migrujących z własnego wyboru, trudniejsze dla osób zmuszonych do migracji.

Pierwsza grupa obejmowała:

1. Tych, którzy migrowali kilkuosobowymi grupami dobrowolnie z własnego wyboru, porzucając rodzinne wioski na rzecz przeniesienia się do pobliskich miast, miasteczek czy w pobliże baz wojskowych. Nie następowało u nich (mimo utraty dobytku materialnego i domostwa) kompletne rozbicie tożsamości i istniejących starych struktur społecznych. Musieli poszukiwać nowych podstaw ekonomicznych, zmieniając swą kulturę i obyczaje ale nie czynili tego gwałtowanie, a tylko dostosowywali się stopniowo do wymogów nowego środowiska, które nie było często tak odległe od ich własnego. Często znane im było z wcześniejszych podróży np. handlowych, obecności na targach w okresach poprzedzających konflikt.

2. Tych, którzy migrowali indywidualnie, ale w obrębie prowincji. Migracja nie wywoływała wśród nich szoku kulturowego. Nie poznali trudności językowych mogli porozumiewać się z otoczeniem. Język Kiczua i pochodzenie $z$ terenów wiejskich ułatwiało im, a nie utrudniało kontakty. Byli przez przyjmujące środowisko traktowani jako ofiary wojny. 
Trudniejsza była sytuacja 2 innych grup:

1. Tych, którzy zostali zmuszeni do opuszczenia własnych domów wskutek: kompletnej dewastacji ich miejsc zamieszkania, wypalonych, zbombardowanych wsi.

2. Tych, którzy uciekali, bo znajdowali się na czarnych listach sendero lub wojsk.

Te migracje miały na ogół charakter interregionalny, a przyjmujące je grupy znajdując się z dala od teatru wojny traktowały ich nierzadko jak intruzów, zalewających ich własne środowisko.

Sytuacja migrujących uzależniona była też od kierunków migracji w kierunku wschodniej selvy oraz na tereny wybrzeża. Migrujący do wschodniej selvy na dłuższy czas zapewniali sobie spokój, nie mieli też większych problemów bytowych i samoorganizacyjnych. Ich główna trudność polegała na adaptacji do odmiennego środowiska ekologicznego. Mieszkańcy selvy byli otwarci na odmienność przybyszów, gdyż na tych terenach cały czas miały miejsce fluktuacje niewielkich grup ludności napływowej. Mimo izolowanego życia więcej wiedzieli też o wojnie i przemocy, przed którą migranci uciekali, niż mieszkańcy costy. Przesiedleńcy przyjmowani więc byli życzliwie i włączali się bez większych problemów w istniejące lokalne struktury społeczne.

Inaczej było z migrującymi na wybrzeże. Ludność uciekała przede wszystkim do Limy. W Limie setki rodzin z terenów wiejskich miało swych krewnych i powinowatych z wcześniejszych fal migracji lat 70. U nich szukali pomocy. Krewni mieszkańcy stolicy tworzyli nieformalne struktury bardzo pomocne, dostarczali podstawowych informacji, ułatwiali uciekinierom komunikację pełnili funkcje katalizatora ułatwiającego asymilację. Tradycyjne nieformalne więzy i mechanizmy pomocy funkcjonowały szczególnie skutecznie w pierwszej wstępnej fazie migracji. Skala migracji przybrała jednak tak na sile po 1983 r., że z czasem ani krewni, ani organizacje ludowe nie mogły sprostać w niesieniu pomocy przesiedleńcom (ILSA 1994).

Fatalną rolę odegrała też niewiedza limeńczyków na temat rzeczywistej skali przemocy mającej miejsce w Andach (Coronel 2003). Mieszkańcy stolicy nie traktowali migrantów z sympatią i współczuciem, a w większości wypadków wręcz widzieli w nich szarańczę, zakłócającą porządki miejskie. Część nie rozumiała przyczyn nędzy ludności napływowej, większość nie akceptowała odmienności kulturowej i obyczajowej. Odmienność była powodem drwin nawet ze strony tych obywateli, których rodzice przybyli zaledwie kilka lub kilkanaście lat wcześniej także 
z terenów wiejskich, tylko że nie w tak tragicznych okolicznościach (migracja ekonomiczna do miast przełomu lat 60-70).

Miasta, a szczególnie stolica zapewniała jednak przesiedleńcom lat 80-90 sprawdzone wsparcie organizacyjne, do których większość z kobiet z czasem trafiała (Del Pino 2003:61).

Kobiety migrantki próbowały w wypadkach przesiedleń prowincjalnych tworzyć własne oddolne stowarzyszenia przesiedleńców. Starano się w nich wzorować na utraconych tradycjach samorządowych wyniesionych ze wspólnot. Tam, gdzie duże grupy ludności z pobliskich terenów przemieszczały się z w pobliże najbliższych miast, migranci, mimo że uciekający $z$ terenów pochodzenia indywidualnie, nie tracili całkowicie swej tradycyjnej tożsamości. Małe miasta przy niedużej liczbie mieszkańców ułatwiały ludności napływowej odnalezienie powinowatych, sąsiadów bliższych lub dalszych, co silnie spajało w nowym miejscu migrantów. Utrzymywanie nawet nielicznych relacji bezpośrednich było gwarantem tożsamości, których pozbawiani byli migranci interprowincjonalni. $\mathrm{W}$ tym drugim wypadku rozbicie, zagubienie i rozproszenie migrujących wywodzących się z najrozmaitszych terenów o różnych tradycjach sprawiało, że ,ginęli" w środowisku miejskim. W dużych miastach istniały organizacje przesiedlonych, do których niektórzy migranci trafiali. Pomoc zależała jednak od interpretacji powodów przesiedlenia. Ci, którzy winnych widzieli w wojsku i policji byli niechętnie widziani i podejrzewani o kontakty z terrorystami.

Silnym wsparciem dla migrantów wyrównującym mankamenty organizacji oddolnych stały się samopomocowe organizacje kobiece oraz kościelne organizacje - Kluby Matek. Te pierwsze stowarzyszenia mające swoją długą historię w Limie, okrzepłe organizacyjnie stały się podstawą stabilizacji dla większości rodzin przesiedleńców. W wypadku drugich Klubów Matek - rozwinęły się one szczególnie w rejonie Ayacucho i Puno dopiero w okresie przemocy, za sprawą silnego wsparcia najpierw odłamu konserwatywnego Kościoła katolickiego, a po 1985 r. dzięki polityce prezydenta Alana Garcii. Oba typy organizacji wspomagały kobiety - migrantki, ale także za określoną cenę. Tą ceną była zmiana tożsamości i prawdy o pamięci. Tylko w prov. Ayacucho ok. 30 tys. kobiet wchłonęły Kluby Matek. W Limie liczba uczestniczek nie jest znana, ale wzrost liczby Klubów z 20 w 1978 r. do 100 w 1986 r. i 200 w 1995 r. mówi sam za siebie (Blonded 1994, Coral 1999).

Kobiety, znajdując się pod opieką Klubów Matek miały ułatwiony start i pomoc materialną, ale musiały podporządkowywać się obowiązującym 
regułom. Reguły polegały na odrzucaniu zewnętrznych atrybutów indiańskości (ubioru i języka), przyjęcia określonego prorządowego stanowiska wobec przemocy niezgodnego z prawdą i odczuciami wielu kobiet. Udział w Klubach Matek z ww. powodów nie dla wszystkich migrantek był do zaakceptowania. Odejście wiązało się często z kolejnym ciosem, odrzuceniem przez Kościół. Kościół katolicki szczególnie w prow. Ayacucho utożsamiał przemoc wyłącznie z działaniami guerrilli, które wiązał z pochodzeniem indiańskim uczestników. Posiadanie w rodzinie zaginionych, mówienie o przemocy policji czy wojska jako przyczynie migracji, równało się przychylności dla terroryzmu. Duchowni katoliccy nie odwiedzali poza nielicznymi wypadkami terenów wiejskich przez ponad 15 lat, ale narzucali oficjalne stanowisko hierarchów Kościoła wiernym. Migrantki po ciężkich doświadczeniach osobistych, przenosząc się do miast szukały, co naturalne, wsparcia w wierze i możliwości uczestnictwa w życiu religijnym. Demonstrowanie żałoby, wspominanie o przemocy sił narodowych zaznanych w rodzinnych miejscowościach narażało je także na izolację w zakresie życia religijnego. W mniej drastycznej formie, ale podobne stanowisko przyjmowały organizacje ludowe w Limie i organizacje pozarządowe, które teoretycznie nie powinny ulegać naciskom politycznym.

Tak więc organizacje katolickie, ludowe (kobiece) i pozarządowe, których celem było niesienie pomocy, zmieniając prawdziwe przyczyny migracji, poddawały migrantki dodatkowym presjom. Przykładowo w stołówkach ludowych doskonale rozwijających się w Limie nie było można otrzymać posiłków czy mleka dla dzieci o ile mówiło się w języku kiczua. Agresorem - jedynym winnym przemocy - mogły być tylko oddziały guerrilli, co w $40 \%$ nie odpowiadało prawdzie. Kobiety stawały przed nowymi dylematami, takimi jak zapewnienie bytu dzieciom, za cenę wdzięczności wobec tych, których często obwiniały o swe nieszczęścia, akceptacja możliwości uczestnictwa w życiu religijnym, ale za cenę przemilczania prawdy czy odrzucenie pomocy materialnej i wsparcia duchowego w religii poprzez poszukiwania własnej drogi przetrwania.

W ten sposób wymienione wyżej organizacje pośrednio wymuszały i uczyły kobiety milczenia, skrywania swych opinii, nie wspominania o prawdziwych przyczynach ucieczek z terenów pochodzenia. W imię przetrwania fizycznego najbliższych większość kobiet przyjmowała takie zewnętrzne postawy niezgodne $\mathrm{z}$ ich własnymi poglądami, godząc się z oczekiwanymi od nich przez otoczenie. Miasto uczyło je nowych zachowań: zakłamania, hipokryzji i sprytu, które tylko niektóre umiały 
umiejętnie wykorzystać. Niektóre, dostosowując się do narzucanych reguł, doskonale adoptowały się, odnajdując wręcz cel życia we współpracy z organizacjami samopomocowymi. Dla wielu stało się to sposobem odnalezienia w nowej rzeczywistości społecznej, główną formą aktywności, doskonalonej przez następne lata. Organizacje takie dawały możliwości rozwijania szerszych relacji społecznych, nabywania nowych umiejętności, poprawy bytu rodziny, a nawet awansu. Wiele z kobiet uzależniało się wręcz od organizacji kobiecych, pracując w kolejnych planach pomocy. Dziś niektóre $\mathrm{z}$ nich to ujawniają:

„....gdyby nie organizacje pozarządowe, plany pomocy, nie miałabym pracy. Od moich umiejętności przekonywania innych zależy byt mojej rodziny. Nie umiem nic innego...”(Rofelia - migrantka z Vigsuahau).

Większość z migrantek korzystała z pomocy materialnej, ale zamykała się w sobie, dystansowały się na wiele lat od życia społecznego lub pozorowały aktywność proorganizacyjną, co z jednej strony osłabiało autentyczność ruchu z drugiej utrudniało tysiącom kobiet wyjście ze stanu trajektorii często obecnego do dziś.

,... Dzieci gdy uciekaliśmy były zbyt małe, ale opowiadałam im o innym naszym życiu we wspólnocie o świętach, solidarności, gościnności... tęsknota za tamtym życiem towarzyszy mi cały czas, ale żyję tutaj i mogę tylko pamiętać, cierpieć nie mówiąc o tym głośno...” (Augusta).

Tylko nieliczne kobiety odchodziły z organizacji, nie godząc się z koniecznością odrzucenia ich prawdy, ich prawa do pamięci, co wiązało się ze znacznie trudniejszą walką o przetrwanie i zapewnienie bytu rodzinie.

„....próbowałam szukać pomocy w klubie matek, potem organizacji przesiedlonych ale wszędzie miałam zapomnieć kto zabił mojego syna, i ojca, kto spalił nasz dom, dlaczego uciekłam do miasta... Było bardzo ciężko, byliśmy sami, ale dzieci wychowałam. Teraz mamy rodzinę, nowych sąsiadów i pamięć, której nie zniszczyłam...”(Amalia).

$$
* * *
$$

Wstrząs, jakim był długotrwały konflikt zbrojny w Peru, zmienił obraz demograficzny i społeczno-kulturowy kraju. Jednym z podstawowych elementów tego procesu była masowa niekontrolowana migracja $\mathrm{z}$ terenów wiejskich do miast wywołana przemocą polityczną. Co warte pod- 
kreślenia, migracje w pierwszej kolejności wywołane zostały przemocą Państwowych Sił Zbrojnych, a w drugiej guerrilli. Nieodłączną częścią migracji przesiedleńczej stało się kurczenie, zawężanie obszarów zamieszkałych przez ludność pochodzenia indiańskiego na rzecz rozrostu liczby ludności identyfikującej się z kulturą Metyską. Proces ten rozwinął się nie tylko wskutek fluktuacji ludności do miast i wyludniania obszarów wiejskich, ale przede wszystkim w wyniku wymuszanej metysacji kultury, jaką narzucało migrantom miasto. Władze, przedstawiciele różnych organizacji pozarządowych oraz mieszkańcy Limy wywierali różnego rodzaju presje na przybyszach m.in. poprzez instytucje edukacyjne, ekonomiczne, samopomocowe. Nieprzewidzianym, ale pozytywnym efektem migracji przesiedleńczych stały się zmiany w zakresie pozycji społecznej kobiet w kraju. Migracje przesiedleńcze były silnie sfeminizowane. Struktury instytucjonalne istniejące $\mathrm{w}$ miastach poprzez kobiece stowarzyszenia samopomocowe ułatwiały migrantkom start w mieście, ale za cenę odrzucenia ich pamięci o przemocy jako niezgodnej z obowiązującą w kraju i własnej tożsamości indiańskiej. Te organizacje były więc początkowo istotnym instrumentem w metyzacji kulturowej migrantek. Z czasem jak dziś się okazuje poprzez te same organizacje kobiety - zasymilowane już migrantki zaczęły wywierać presję na zmiany w pozycji kobiet w kraju. Byłe migrantki dzięki posiadanym doświadczeniom, wieloletnim negocjowaniem o uznanie swej pozycji, posiadaniu znacznie wyższego stopnia samodzielności społecznej zdobytego dzięki walce o przetrwanie w warunkach miejskich, niezależności ekonomicznej z powodzeniem domagać się zaczęły zmian w sposobie traktowania ich przez machistowskie otoczenie.

\section{Bibliografia}

Blondet C. 1992, En la tierra de nadie: ajuste structural y violencia en las barriadas de Lima, IEP, Lima.

Blondet C. 1995, La situacion de mujer en el Peru 1980-1994, IEP, Lima.

CEPRODEP 1997, Diagnostico de despalzados en Ayacucho 1993-1997, Herores sin nombre, Lima.

Coral I. 1994, Desplazamiento por violencia politica en el Peru 1980-1992, IEP, Lima.

Coronel J. 1999, Efectos de violencia politica en Ayacucho, Lima

Cuanto (ed. R. Webb) 1980, Peru en numeros, Lima.

Cuanto (ed. R. Webb) 1991, Peru en numeros, Lima. 
Cuanto (ed. R. Webb) 2001, Peru en numeros, Lima.

Cuanto (ed. R. Webb) 2003, CVR - Raporte de la Comision de la Verdad y Reconsilacion, t. VI, Lima.

Cuanto (ed. R. Webb) 2004, Hatun Willakuy - version abreviada del Informe Final de la Comision de la Verdad y Reconsilacion, IEP, Lima.

Degregori I., Blondet C., Lynch N. 1986, Conquistadores de un Nuevo mundo. De invasores a ciudadanos en San Martin de Porres, Lima.

Del Pino P. 2003, Retorno de comunidades desplazados por la violencia, Lima.

Diez A. 2003, La problematica de los desplazados, IEP, Lima.

Franco C. 1992, Reflexiones sobre otra modernidad, CEPES, Lima.

Golte J., Adams N. 1990, Los caballos de Troya de los invasores a Lima, IEP, Lima.

ILSA 1994, Informe sobre servicios legales a sectores marginados en el Peru, Bogota.

INEI - Instituto nacional de Estadistica e Informatica 1998, „Peru: resultados definitivos", nr 10, Lima.

Revollar E. 2000, Los desplazados por violencia politica en el Peru, „Allpanchis” nr 55, Puno.

Tamayo G. 1992, Desplazamiento, genero y desarrollo, Informe UNIFEM-PNUD, Lima.

Varillas A. 1990, La situacion poblacional peruana.Balance y perspectives, INADEP, Lima.

www.cvr.org.pe.

\section{Summary}

The shock of the lengthy military conflict in Peru changed the demographic, social and cultural outlook of that country. One of the basic elements of this process was uncontrolled mass migration from rural areas to towns, brought about by political violence.

Displacement migrations were strongly feminized. Institutional structures that emerged in towns, via women's self-assistance societies facilitated the migrants' acclimatization in towns. However, they had to pay a price and to reject their memories of violence by denying the Indian identity of the state and their own. Therefore, these organizations were initially, a significant element of cultural mestization of female migrants. Now it transpires that the same organizations were used by the women and then the assimilated migrants, to exert pressure demanding that the position of women in Peru be changed. Former female migrants, who acquired experience and who, for many years negotiated that their status be acknowledged, had a significantly higher degree of social independence because of their struggle to survive in urban conditions. They were also financially independent and began to successfully demand that their macho environment treat them in a different manner. 